\title{
¿Un riñón en vista longitudinal y el otro transversal?
}

One kidney in a longitudinal view and the other one in a transversal view?

\section{Juan Miyahira ${ }^{1}$}

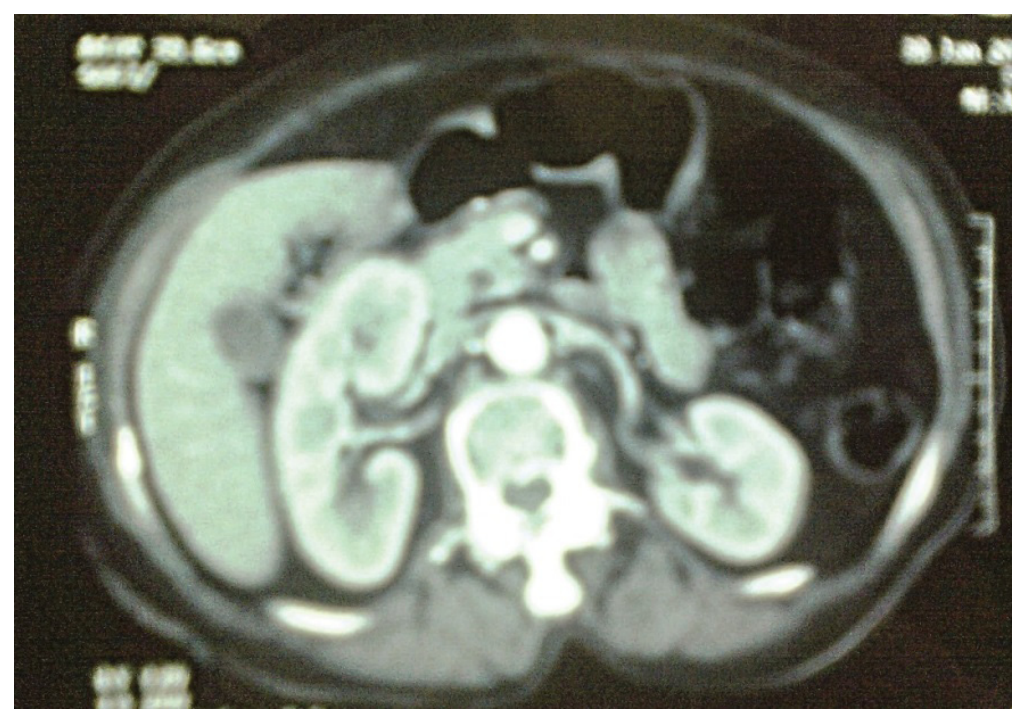

Imagen de una tomografía computarizada en la que se observa el riñón derecho en corte longitudinal y el riñón izquierdo, transversal. ¿Cómo se puede explicar esto? A diferencia de las anomalías de la rotación renal (mala rotación) en las que la rotación es en el eje vertical, en esta imagen, el riñón derecho esta rotado en el eje horizontal. La interpretación es que existe "algo" que está desplazando el polo inferior del riñón derecho hacia adelante y hacia arriba. Esta imagen corresponde a una mujer adulta mayor quien tenía una tumoración retroperitoneal que desplazaba el polo inferior del riñón derecho hacia arriba y adelante; la paciente fue programada para ser intervenida quirúrgicamente.

How can you explain that one kidney is observed in a longitudinal view and the other one in a transversal view in an abdominal CT scan? In this image, opposed to what is seen in anomalies of kidney rotation where the rotation occurs in the vertical axis, the right kidney is rotated in the horizontal axis. The explanation is that something is displacing upward and anteriorly the inferior kidney pole. We present the case of an elder female patient with a retroperitoneal mass that displaced the right kidney; the patient was scheduled for a surgical intervention.

1. Médico especialista en Nefrología, Hospital Nacional Cayetano Heredia. Profesor Principal, Facultad de Medicina Alberto Hurtado. Universidad Peruana Cayetano Heredia. Lima, Perú. 